\title{
Early childhood education and care of children with normal and abnormal development in Poland - its importance and barriers
}

\begin{abstract}
Marzena Buchnat, Aneta Wojciechowska, Early childhood education and care of children with normal and abnormal development in Poland - its importance and barriers. Interdisciplinary Contexts of Special Pedagogy, no. 24, Poznań 2019. Pp. 67-81. Adam Mickiewicz University Press. ISSN 2300-391X. DOI: https://doi. org/10.14746/ikps.2019.24.04
\end{abstract}

The article presents a discussion on the importance of early therapeutic interactions for the development of a child at risk of disability or with a disability and his/her family. It indicates the importance of the time of taking action in relation to a child with developmental disorder for the period from birth to the age of three years. The article pays special attention to the place of early intervention and early support in the development process, its preventive, compensatory and corrective role. It describes barriers to the development of this system in Poland and points to potential solutions to these difficulties.

KEY WORDS: early childhood education and care system, a child with abnormal development, education, care

In recent years, increasing attention has been paid to the quality of early childhood education and care. According to the lifelong learning approach, where the education process continues from the 
beginning to the end of life, the early stages of education in the first three years of a child's life and pre-school education are vital. "Research shows that investing in early education and lifelong learning yields measurable and substantial social and economic benefits"1. Because of this, the Council of the European Union highlighted the need for introducing a systematic and integrated approach to early childhood education and care based on comprehensive cooperation of all the stakeholders of the social system². The guidelines for the quality of the early childhood education and care system promoted by the European Commission are based on the standards for the quality of services provided to young children developed by UNICEF. They determine the family and social context and the management of the early childhood education and care system, and describe access to services and their quality. Among other things, they highlight the need to outreach with services to all families with young children. Access to early education and care should be common, which means that fees should be suited to the possibilities of citizens. The guidelines also suggest that a special focus should be placed on children in risk groups. Services should be addressed to them in the first place, with the possibility to include additional or specialist services ${ }^{3}$.

The basic argument for providing early support to child development is the scientific awareness of the "sensitive periods" for brain development ${ }^{4}$. The exceptional plasticity of the brain in the early period of development gives more opportunities for change.

1 A.I. Brzezińska, M. Czub, Wczesna opieka i edukacja dzieci w Polsce w kontekście europejskim, „Polityka edukacyjna: wyzwania i szanse” 2012, no. 1, p. 15-19.

2 Council of the European Union, Official Journal of the European Union (OJ C 175/03 of 15.06.2011), 2011.

${ }^{3}$ J. Bennet, Benchmarks for Early Childhood Services in OECD Countries, "Innocenti Working Paper", UNICEF Innocenti Research Centre, Florence 2008.

${ }^{4}$ European Network of National Observatories on Childhood, Early Childhood Education and Care Services in the European Union Countries. Proceedings of the ChildONEurope Seminar and integrated review. Istituto degli Innocenti. Firenze 2010, p. 12. 
The brain of a young child learns the fastest, as observes Małgorzata Kossut $^{5}$, it absorbs more information and more intensely develops in motor terms, as a result of which even major brain damage can be compensated for. This is the result of the reorganization of the central nervous system (CNS), because specialist areas of the cerebral cortex and extrapyramidal system are ready and able to change their specificity. It is believed that, thanks to the lability of the network of protein fiber structures (cytoskeleton) and a large ability of the axons and dendrites to grow, new neural connections developed, modified by a type of external stimuli, which is synonymous with activating specific neural paths. The neuroplasticity of the brain in the first years of life is particularly important for children with progressive disorders, because early interaction increases chances for inhibiting, or sometimes even stopping negative developmental changes. Human brain is capable of regeneration, thanks to its plasticity, which enables changes in the function of facilitating or inhibiting synaptic transmission and changes in the neural branches of axons, dendrites and synapses ${ }^{6}$. Learning causes plastic strengthening of synaptic connections, and the stronger they are and the more branches they have, the more effective is the process of acquiring new knowledge and skills. The neuroplasticity of the brain also involves adjustment of the nervous system to changes in the external or internal environment ${ }^{7}$. In childhood, the brain is ready to receive various information but, if it has not encountered specific information, it does not "see" the need to maintain the circuits responsible for their receipt, as the white matter (i.e. the processes of the nerve cell bodies through which information is sent from cell bodies to the synapses that connect neurons) is better de-

${ }^{5}$ M. Kossut, Neuroplastyczność, [in:] Mózg a zachowanie, ed. T. Górska, A. Grabowska, J. Zagrodzka, PWN, Warszawa 2012.

${ }^{6}$ M. Pąchalska, B.L.J. Kaczmarek, J.D. Kropotov, Neuropsychologia kliniczna. Od teorii do praktyki, PWN, Warszawa 2014.

7 J. Skibska, Neuroplastyczność mózgu wsparciem rozwojowym dziecka we wczesnym dzieciństwie, "Zeszyty Naukowe Wyższej Szkoły Humanitas. Pedagogika” 2015, no. 10, p. 79-92. 
veloped in persons who start training a skill earlier that in persons who start learning after the puberty period ${ }^{8}$. Thus, in the infancy, post-infancy and middle childhood periods, it is necessary to provide experiences to and stimulate the senses. At this stage of development, children learn more easily and it takes shorter for them to generate the skills and habits they have learned. The changes that taka place in the CNS in this age are possible thanks to the developmental plasticity, which facilitates learning and memory, while functional plasticity enables the development of new skills and competencies ${ }^{9}$. It is necessary to provide children with developmental deficits with support and stimulation in order to rebuilt the skills they have lost. Children are more reactive to therapy, because their brain continues to synthesize myelin, which increases the rate of transmission of neural impulses. This increases the reactivity of young children to rehabilitation programs and enables them to progress faster. Research conducted by Elkhonon Goldberg ${ }^{10}$ shows that the involvement of young children in extra cognitive activity stimulates the development of local neural connections and increases the number of neurons. Also, research conducted at the Salk Institute in San Diego and at Princeton University shows that regular mental exercises in early childhood cause developmental changes that enable more effective dealing with complex intellectual tasks and stimulate changes in the hippocampus, which is responsible for the functioning of memory and assimilation of knowledge ${ }^{11}$. Considering the plasticity of the brain and the priority rights with respect to learning (the first skills are the most fixed and the most difficult to change later), children with developmental difficulties must mandatorily be included in early rehabilitation and educational interactions, since,

8 Ibidem.

${ }^{9}$ A.R. Borkowska, Ł. Domańska, Plastyczność mózgu, [in:] Podstawy neuropsychologii klinicznej, ed. Ł. Domańska, A.R. Borkowska, UMCS, Lublin 2013, p. 113-128.

10 E. Goldberg, Jak umyst rośnie w sitę, gdy mózg się starzeje, PWN, Warszawa 2014, p. 267-268.

11 A.D. Bragdon, D. Gamon, Rozwiń swój umyst. Ćwiczenia dla lewej pótkuli mózgu, Wydawnictwo LIBER, Warszawa 2010, p. 13 
as Maria Pąchalska ${ }^{12}$ states, brain damage in early childhood is thanks to the functional reorganization of the brain - easier to repair and compensate for than damage in mature age.

Early childhood is mainly the time when a child, by establishing relations with the caregiver and having contacts with the environment, creates a representation of him or herself and the surrounding reality ${ }^{13}$. Early experiences associated with the development of relations with parents/caregivers are of vital importance for the person's functioning in all developmental areas in subsequent periods of life. According to John Bowlby's ${ }^{14}$ theory of attachment, people have a tendency to create strong, affective bonds with important others. Such bond is characterized by selectivity (focusing on a specific person who triggers attachment behaviors in a way and scope not manifested in relations with another person), searching for physical proximity with the object of attachment, a sense of comfort and security resulting from the achievement of proximity and separation fear when it is not possible to achieve proximity or when the bond is broken. Contemporary research on the development of attachment shows its vital importance for later emotional and social functioning ${ }^{15}$. The role of attachment is important for building and increasing a sense of security in a child, but it also stimulates the development of internalized cognitive structure and is the basis for personality development. Providing early support for the development of positive bonds will thus implicate increased quality of life.

12 M. Pąchalska, Rehabilitacja neuropsychologiczna. Procesy poznawcze i emocjonalne, UMCS, Lublin 2008.

13 I. Bretherton, K. Munholland, Internal Working Models in Attachment Relationships: A Construct Revisited, [in:] Handbook of attachment. Theory, research and clinical application, ed. J. Cassidy, Ph.R. Shaver, The Guilford Press, New York 1999, p. 90-101.

14 J. Bowlby, Attachment and Loss: Volume 1. Attachment, Penguin Bookszanse, New York 1982.

15 A.I. Brzezińska, K. Appelt, B. Ziółkowska, Psychologia rozwoju człowieka, [in:] Psychologia: Podręcznik akademicki, vol. 2, ed. J. Strelau, D. Doliński, GWP, Gdańsk 2010, p. 95-290. 
The results of research on attachment mainly emphasize the role of early experiences with caregivers in the process of developing a child's ability to control emotions and cope with stress, which is of key importance for his or her further cognitive and social functioning, associated, among other things, with learning in educational institution, working and functioning in the family and wider social groups ${ }^{16}$.

The quality of care will indicate the special role of a professional responsible for the organization of early childhood education and care, but also for providing support to the parents of a young child. The paradigm of providing early family-focused support of child development is based on seven assumptions:

1) the assistance provided strengthens the family;

2) the relations between professionals and parents are regular;

3) family life is the context for early support of child development;

4) supportive interactions should focus on family strengths and its future plans;

5) professionals encourage parents to make choices and decisions;

6) assistance provided to a family should be customized and flexible;

7) professionals and partners are partners in their mutual relationship and communication ${ }^{17}$.

A major element of the early support of child development is to plan regular interactions with the aim of developing such relations between the caregivers and the child that will be the most beneficial for his or her physical, psychological and social functioning 18 .

In the Polish care system of young children at risk of disability or diagnosed with a disability, there are two areas of supporting

16 A.I. Brzezińska, M. Czub, op. cit., p. 16

17 A. Twardowski, Rola upetnomocnienia rodziców w procesie wczesnego wspomagania rozwoju dzieci z niepetnosprawnościami, „Niepełnosprawność. Dyskursy pedagogiki specjalnej" 2016, no. 24, p. 200-211.

18 A. Twardowski, Wczesne wspomaganie rozwoju dzieci z niepetnosprawnościami w środowisku rodzinnym, Wydawnictwo Naukowe UAM, Poznań 2014, p. 131. 
child development: 1) early support of development; and 2) early intervention.

Early support of development is an educational measure that is supposed to stimulate the psychomotor and social development of a child from the moment when disability is diagnosed until the child goes to school ${ }^{19}$. Early intervention is a measure that encompasses a number of multispecialist diagnostic and therapeutic interactions involving a child and his or her family, enabling the earliest possible detection of developmental difficulties and minimizing them so that the child achieves an optimum level of development in the motor, intellectual, emotional and social areas ${ }^{20}$. In the Polish law, however, there is no definition of disability, which, consequently, makes it difficult to issue documents that will entitle children to be included in therapeutic interactions. Local teams that confirm disability apply different criteria to award disability benefits than educational institutions (psychological and pedagogical counseling centers) that issue special needs education statements. The regulation governing the organization of early support of child development does not specify which of the definitions of disability (medical or educational) is to be considered in decisions on providing a child and his or her family with early support of development. In practice, some counseling centers use the concept of "disability" contained in the instrument governing the issuance of special needs education statements, while other go beyond that definition. This is mainly associated with to the fact that some children diagnosed with "retarded psychomotor development" or "retarded speech development" are treated as disabled according to medical regula-

${ }^{19}$ A. Wojciechowska, Wczesna interwencja i wspomaganie dziecka $z$ niepetnosprawnościa, [in:] Dzieci i młodzież z niepetnosprawnościa intelektualna w systemie edukacji, ed. M. Buchnat, B. Tylewska-Nowak, Difin, Warszawa 2012, p. 29; Rozporządzenie Ministra Edukacji Narodowej z dnia 24 sierpnia 2017 r. w sprawie organizowania wczesnego wspomagania rozwoju dzieci (Dz.U. poz. 1635).

${ }^{20}$ M. Kastory-Bronowska, Z. Pakuła, Z., Wczesna interwencja, Wydawnictwo Polskie Stowarzyszenie na Rzecz Osób z Upośledzeniem Umysłowym, Warszawa 2002, p. 7. 
tions, but not according to educational regulations. Thus, some children with abnormal development do not receive relevant therapeutic interaction, because they do not fall under the definition of "disability" used by a given institution. This could be solved by applying the medical classification criteria ICD-10, which would make early support much more accessible to children at risk of disability, with retarded development, retarded speech or genetic syndromes, since the diagnosis of e.g. the Down syndrome in itself is not enough for a counseling center to issue a referral for early support of development.

Another problem frequently faced by parents of children with disabilities or at risk of disabilities is shortage of institutions offering early intervention and early support of development. According to the report of the Stowarzyszenie Pomocy Dzieciom z Ukrytymi Niepełnosprawnościami im. H. Aspergera „Nie-grzeczne dzieci” (Association for Children with Invisible Disabilities Named After H. Asperger "Im-Polite Children")21, despite favorable legal regulations, based on which early support of development may be provided (apart from psychological and pedagogical counseling centers) by any pre-school and school, if only they have "the possibility to implement the recommendations of a referral for early support of development, in particular teaching aids and equipment necessary to provide early support 22 , the parents of children with a referral for early support of development have problems finding an institution that will provide such support, especially the more specialist forms of support, such as spatial orientation, sensory integration or speech therapy.

The benefits of attending early intervention and early support activities are huge. Children who attend such activities, by experi-

21 A. Braun, A. Niedźwiedzka, Wczesne wspomaganie rozwoju dziecka. Problemy i wyzwania. Stowarzyszenie Pomocy Dzieciom z Ukrytymi Niepełnosprawnościami im. Hansa Aspergera „NIE-GRZECZNE DZIECI”, Warszawa 2015.

22 Rozporządzenie Ministra Edukacji Narodowej z 11 października 2013 r. w sprawie organizowania wczesnego wspomagania rozwoju dzieci, Dz.U. 2013 poz. 1257. 
encing relations with other people, increase their social and emotional skills and their ability to adapt to new conditions, and positive adaptive experiences make it easier for them to settle down in a pre-school or school, thus giving them a better educational start. Also, cognitive activation of a child conditions optimum functioning of the brain, which influences the process of learning and acquiring knowledge about the surrounding world, and developing curiosity and creativity. Participation in specialist activities covering early intervention and early support of development also stimulates the independence and resourcefulness of children. For the parents, such activities are mainly a source of information on the child's development. They are a chance to increase parenting skills in terms of satisfying the needs of children. For the parents of children with abnormal development, they may be a source of support and road sign to receive professional assistance. Therapeutic interactions in early intervention and early support of development also include activities aimed at supporting the family and building its emotional and social potential to care for and bring up a child with disability. It is also a chance to build a space for the exchange of experiences between parents of children with development disorders. This is an opportunity for social integration and acquisition of new skills.

Despite the fact that early therapeutic interactions are of vital importance for the development of a child and beneficial for the family as well as for the society, in Poland they are still insufficient. When analyzing the standards promoted in Europe and across the world, it should be sadly concluded that Poland is far behind in terms of most indicators ${ }^{23}$, which is due, among other things, to:

- a divided system of early childhood education and care (e.g. children up to 3 years of age are covered by the Ministry of

${ }^{23}$ Children in Scotland, Country profile: Poland. A report for the cross-European programme Working for Inclusion: the role of the early years workforce in addressing poverty and promotion social inclusion, Edinburgh 2010, http://www.childrenin scotland. org.uk [accessed on: 8.12.2018]. Children in Scotland, Working for Inclusion: how early childhood education and care (ECEC) and its workforce can help Europe's youngest citizens, Edinburgh 2010 http:/ / www.childreninscotland.org.uk [accessed on: 8.12.2018]. 
Labor and Social Policy, while children older than 3 years - by the Ministry of Education; nurseries and pre-schools are financed from different sources - partly by local authorities and partly by parents);

- the lowest, alongside the Czech Republic, ration of children up to 3 years included in institutionalized education and care;

- lower - compared to countries with a higher quality of the life of children - percentage of children included in preschool education;

- low involvement of parents in preschool and school education, such as planning the interactions, cooperating with the teachers, access to information about a child" 24 .

In consideration of the above deliberations on the accessibility of early therapeutic interactions to children at risk of disability or disabled, the Polish system of caring for a young child with abnormal development and supporting his or her family requires many changes. They are the most needed with respect to children who have disabilities and require special care, who, in accordance with the Council of Ministers report on the implementation of the Act on the Care of Children Aged Below 3 Years of 4 February 2011 (Journal of Laws/ Dz.U./ of 2016, item 157), in 2015 constituted appr. 1\% of children using nurseries, kids clubs and nannies, and $2 \%$ in kids clubs. For these children, it is extremely vital in their development, because the earlier a child is diagnosed and provided with stimulation and support of development, the more chances he or she will have to achieve an optimum level of functioning.

The reasons for the difficulties associated with proper provision of early childhood care can be found in the report of the team of the Fundacja Rozwoju Dzieci im. J.A. Komeńskiego (Foundation for Children Development Named After J.A. Komeński) and the PolishAmerican Freedom Foundation associated with their work to strengthen the civic society and ensure equal chances in Poland.

${ }^{24}$ A.I. Brzezińska, M. Czub, op. cit., p. 17. 
The results of the research conducted by the team suggest that the barriers may be caused by ${ }^{25}$ :

- limited knowledge of the needs and development of a young child (especially aged between 0 and 3 years) both among parents and professionals;

- narrow understanding of education, limited to school education and underestimating early childhood and non-institutional education. Research results show that interactions with children aged below three years are mainly understood as providing care, not education to the youngest children;

- transferring responsibility for a child to educational institutions, especially when parents have limited knowledge of supporting the development of a young child, and lack of cooperation between institutions and parents;

- no space for children with disabilities to spend time on their own or with parents. The data presented in the report suggest that only $1 \%$ of children with disabilities attend preschools and that there is a shortage of inclusive classes and other forms of supporting the development of children with disabilities aged between 0 and 5 years (early support and early intervention institutions);

- difficult to receive information on children from local authorities. The persons and organizations that work for the disabled find it difficult to acquire reliable and updated information on the number of children with disabilities in a municipality, the type of their disabilities and the year of birth. Thus, they cannot undertake preventive measures and all they can do is to intervene when there already are some irregularities;

- distribution of therapeutic interactions among various institutions, as a result of which professionals cannot communicate with each other on the means of interaction and standardize

${ }^{25}$ A. Giza, M. Wiśnicka, W czym jest problem?, [in:] Edukacja małych dzieci - standardy, bariery, szanse, ed. A. Giza, Fundacja Rozwoju Dzieci im. J.A. Komeńskiego, Warszawa 2010, p. 18-28. 
the support process, and the parents' knowledge about the condition of their child is too limited, which makes it impossible to exchange information between professionals;

- problems with diagnosing the skills and deficits of children, which is due to the fact that professionals are not properly trained to diagnose young children. Based on the above deliberations on the early childhood education and care system for children at risk of disability or with disabilities in Poland, it may be concluded that these measures require constructive, long-term changes. Such changes should result not only from European Union directives, but mainly from social awareness of the importance of the first few years of life for the latter, overall functioning of a person. These changes should include, among other things:

1 ) raising parents' awareness of the needs and developmental possibilities of a child in the early period of life ( 0 to 5 years),

2) increasing the qualifications of professionals (both in the education and healthcare sectors) in functional diagnosis and early detection of developmental retardation,

3) introducing a uniform definition of the term of "disability" in the healthcare and education sectors,

4) increasing accessibility of institutions that provide early intervention and early support of development,

5) providing institutions with specialist equipment and access to professionals,

6) better availability of lists of institutions offering assistance to children with abnormal development and their families in a given area,

7) increasing the awareness of professionals and parents of children with disabilities of the importance of integrated and coherent interactions with various professionals,

8) developing reliable and understandable guidebooks for the parents of children with disabilities on the possibilities to support the child's development in a given area, availability of institutions, social benefits, etc., 
9) developing municipal databases on children with disabilities and their families, which would facilitate the development of an early support system for a young child with developmental disorders in a given municipality.

Introducing the above changes could help increase the quality of the early childhood education and care system for children at risk of disabilities or with disabilities in Poland as well as the effectiveness of interactions with a young child that directly translate to having equal chances in life.

\section{Bibliography}

Bennet J., Benchmarks for Early Childhood Services in OECD Countries, Innocenti Working Paper UNICEF Innocenti Research Centre, Florence 2008.

Borkowska A.R., Domańska Ł., Plastyczność mózgu, [in]: Podstawy neuropsychologii klinicznej, ed. Ł. Domańska, A.R. Borkowska, UMCS, Lublin 2013, p. 113-128.

Bragdon A.D., Gamon D., Rozwiń swój umyst. Ćwiczenia dla lewej pótkuli mózgu. Wydawnictwo LIBER, Warszawa 2010.

Braun A., Niedźwiedzka A., Wczesne wspomaganie rozwoju dziecka. Problemy i wyzwania. Stowarzyszenie Pomocy Dzieciom z Ukrytymi Niepełnosprawnościami im. Hansa Aspergera „NIE-GRZECZNE DZIECI”, Warszawa 2015.

Bretherton I., Munholland K., Internal Working Models in Attachment Relationships: A Construct Revisited, [in:] Handbook of attachment. Theory, research and clinical application, ed. J. Cassidy, Ph.R. Shaver, The Guilford Press, New York 1999, p. 90-101.

Brzezińska A.I, Czub M., Wczesna opieka i edukacja dzieci w Polsce w kontekście europejskim. Polityka społeczna, „Polityka edukacyjna: wyzwania i szanse” 2012, no. 1, p. 15-19.

Bowlby J., Attachment and Loss: Volume 1. Attachment. Penguin Books, New York 1982

Brzezińska A.I., Appelt K., Ziółkowska B., Psychologia rozwoju człowieka, [in:] Psychologia: Podręcznik akademicki, vol. 2, ed. J. Strelau, D. Doliński, GWP, Gdańsk 2010, p. 95-290.

Brzezińska A.I., Czub M., Czub T., Krótko- i długofalowe korzyści z wczesnej opieki nad dzieckiem i edukacji. Polityka społeczna, „Polityka edukacyjna: wyzwania i szanse” 2012, no. 1, p. 15-19.

Brzezińska A.I., Nowotnik A., Funkcje wykonawcze a osiagnięcia szkolne dzieci w wieku przedszkolnym i wczesnoszkolnym, „Edukacja” 2012, no. 1, p. 61-74. 
Children in Scotland, Country profile: Poland. A report for the cross-European programme Working for Inclusion: the role of the early years workforce in addressing poverty and promotion social inclusion, Edinburgh, 2010a, http://www.childreninscotland. org.uk [accessed on: 8.12.2018].

Children in Scotland, Working for Inclusion: how early childhood education and care (ECEC) and its workforce can help Europe's youngest citizens, Edinburgh, 2010b, http://www.childreninscotland.org.uk [accessed on: 8.12.2018].

Czub M., Wiek niemowlęcy. Jak rozpoznać potencjat dziecka?, [in:] Psychologiczne portrety cztowieka. Praktyczna psychologia rozwojowa, ed. A.I. Brzezińska, GWP, Gdańsk 2005, p. 48-56.

European Network of National Observatories on Childhood, Early Childhood Education and Care Services in the European Union Countries. Proceedings of the ChildONEurope Seminar and integrated review. Istituto degli Innocenti: Firenze 2010.

Giza A., Wiśnicka M., W czym jest problem?, [in:] Edukacja matych dzieci - standardy, bariery, szanse, ed. A. Giza, Fundacja Rozwoju Dzieci im. J.A. Komeńskiego, Warszawa 2010, p. 18-28.

Goldberg E., Jak umyst rośnie w site, gdy mózg się starzeje, PWN, Warszawa 2014.

Kastory-Bronowska M., Pakuła Z., Wczesna interwencja, Wyd. Polskie Stowarzyszenie na Rzecz Osób z Upośledzeniem Umysłowym, Warszawa 2002

Kossut M., Neuroplastyczność, [in:] Mózg a zachowanie, ed. T. Górska, A. Grabowska, J. Zagrodzka, PWN, Warszawa 2012.

Mendel M., Rodzina a edukacja małego dziecka, [in:] Mate dziecko w Polsce. Raport o sytuacji edukacji elementarnej, ed. T. Szlendak, Fundacja Rozwoju Dzieci im. J.A. Komeńskiego, Warszawa 2006, p. 150-163.

Pąchalska M., Rehabilitacja neuropsychologiczna. Procesy poznawcze i emocjonalne. UMCS, Lublin 2008.

Pąchalska M., Kaczmarek B.L.J., Kropotov J.D., Neuropsychologia kliniczna. Od terii do praktyki, PWN, Warszawa 2014.

Council of the European Union, Official Journal of the European Union (OJ C 175/03 of 15.06.2011)..

Rozporządzenie Ministra Edukacji Narodowej z 24 sierpnia 2017 r. w sprawie organizowania wczesnego wspomagania rozwoju dzieci (Dz.U. poz. 1635).

Skibska J., Neuroplastyczność mózgu wsparciem rozwojowym dziecka we wczesnym dzieciństwie, „Zeszyty Naukowe Wyższej Szkoły Humanitas. Pedagogika” 2015, no. 10, p. 79-92.

Sprawozdanie Rady Ministrów z realizacji Ustawy z dnia 4 lutego 2011 r. o opiece nad dziećmi w wieku do lat 3 (Dz.U. z 2016 r. poz. 157) w 2015 r., file:///C: /Users/wse/Desktop/Artyku\%C5\%82y/Opieka/sprawozdanie_opieka_nad_ dzieckiem_do_lat_3.pdf [accessed on: 10.06.2017]. 
Twardowski A., Rola upetnomocnienia rodziców w procesie wczesnego wspomagania rozwoju dzieci z niepetnosprawnościami, „Niepełnosprawność. Dyskursy pedagogiki specjalnej" 2016, no. 24, p. 200-211.

Twardowski A., Wczesne wspomaganie rozwoju dzieci z niepetnosprawnościami w środowisku rodzinnym, Wydawnictwo Naukowe UAM, Poznań 2014.

Wojciechowska A., Wczesna interwencja i wspomaganie dziecka z niepetnosprawnościa, [in:] Dzieci i młodzież z niepetnosprawnościq intelektualna w systemie edukacji, ed. M. Buchnat, B. Tylewska-Nowak, Difin, Warszawa 2012. 